\title{
The Study of Employment Promotion by the Entrepreneurship of Chinese Youth under the New Pattern of Integration of Urban and Rural Areas
}

\author{
Lizhuang Liu $^{1}$ \\ ${ }^{1}$ School of Management, Shanghai University of Engineering Science, Shanghai, China \\ Correspondence: Lizhuang Liu, School of Management, Shanghai University of Engineering Science, Shanghai \\ 201600, China. Tel: 86-150-2650-9661. E-mail: 1lz0515sff@163.com
}

Received: December 22, 2013 Accepted: December 31, 2013 Online Published: December 31, 2013

doi:10.5430/wjss.v1n1p62 URL: http://dx.doi.org/10.5430/wjss.v1n1p62

\begin{abstract}
Currently, Chinese economy is in the state of transition. A large number of Chinese youth lost their jobs caused by the excess production capacity. In addition, the college graduates across the country keep increasing year by year, whose number has reach the peak in 2013. Even the quantity of job application is falling. It is well-known to us that rural youth can't be equal to city jobs for the reason that most of them are short of professional skill which is necessary for them to live in the city. Therefore, the employment situation of Chinese youth is on the edge of the grave. The Central committee of Communist Party of China has redefined the connotation of the Urban-rural Integration at the Third Plenary Meeting of the 18th Session of CPC. It is the rural land that creates an opportunity of employment in the process of urbanization. As a result, it can arouse the pattern of collaborative entrepreneurship between the rural youth and college students.
\end{abstract}

Keywords: Integration of Urban and Rural Areas, Entrepreneurship of Youth, employment, improvement, modernization

\section{Introduction}

The current economic structure of China is in a transition phase. Eliminating excess and backward production capacity to China will bring heavy pressure on the job market. More and more young people will be exposed to the risk of unemployment in the transition process. In addition, according to the survey statistics, in 2013, there are 6.99 million of college graduates in a nationwide, which is an increase of 190,000 over 2012. While national plans to recruit post an average reduction about $15 \%$. Since the education level, labor skills, access to resources and so on, they can not be qualified to work in the rapid urbanization process. Obviously they will be unemployment inevitable. It is apparent that situation of Chinese youth employment is quite grim. In the Third Plenary Session of the eighth meeting of this year, the CPC Central Committee made a new pattern of Integration of Urban and Rural Areas. Under the new policy, rural land will create unlimited opportunities for employment in speeding up the process of urbanization, which can stimulate inspiration of the model that rural youth and college students' joint venture, which can promote employment through entrepreneurship.

\section{Definition, Dipartition, and Current Situation of Chinese Youth}

\subsection{Definition}

Academia define youth based on the socialization process includes:

Table 1. Definition of Young People

\begin{tabular}{lcc}
\hline Standard & Years & Time \\
\hline UNESCO & $14-34$ & 1982 \\
World Health Organization & $14-44$ & 1992 \\
United Nations Population Fund & $14-24$ & 1998 \\
\hline
\end{tabular}




\begin{tabular}{lll}
\hline United Nations General Assembly & $15-24$ & 1995 \\
National Bureau of Statistics & $15-34$ & Census \\
League Prospectus & $14-28$ & \\
China Youth Federation & $18-40$ & \\
HK, Macao,Taiwan & $10-24$ & \\
\hline
\end{tabular}

Source: Research Report of China Youth Employment and Entrepreneurship, 2009

Description: We can see the definition of young people by different organizations.

\subsection{Dipartition}

In China, statistics are used more from National Bureau of Statistics that from 15 to 30 years old. Such division can be coincided with management, sociology and economics. It would be in line with partition which is mostly on the basis of education, employment status and survival status.

We can get a clear understanding about overall condition from the following table based on the data of 2009 .

Table 2. Dipartition of Young People

\begin{tabular}{llll}
\hline Basis of Dipartition & Sort & Number(billion) & Proportion(percentage) \\
\hline Urban-rural structure & Rural Youth & 0.186 & 60.5 \\
\cline { 2 - 4 } & Urban Youth & 0.121 & 39.5 \\
\hline Type structure & Reading Youth & 0.072 & 23.6 \\
\cline { 2 - 4 } & Employed Youth & 0.229 & 74.5 \\
\cline { 2 - 4 } & Unemployed Youth & 0.006 & 1.9 \\
\hline Education level & Illiteracy & 0.003 & 1 \\
\cline { 2 - 4 } & Primary & 0.037 & 12 \\
\cline { 2 - 4 } & Junior High & 0.193 & 63 \\
\cline { 2 - 4 } & Senior Middle & 0.052 & 17 \\
\cline { 2 - 4 } & Higher Education & 0.021 & 7 \\
\hline & $16-19$ & 0.108 & 35.2 \\
\cline { 2 - 4 } & $20-24$ & 0.092 & 30.1 \\
\cline { 2 - 4 } & $25-30$ & 0.107 & 34.7 \\
\hline
\end{tabular}

Currently, Chinese youth employment situation is a state of unprecedented in history. We can draw some conclusion from the following chart:

Source: Research Report of China Youth Employment and Entrepreneurship, 2009 


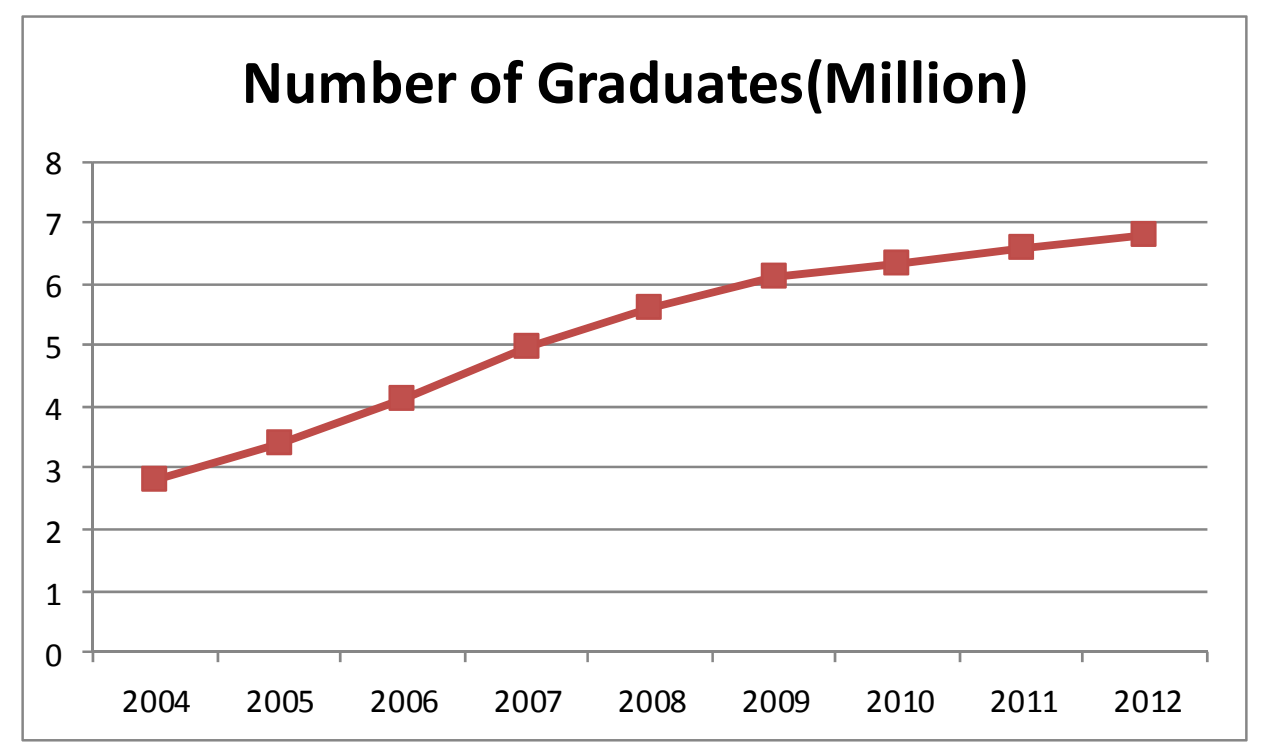

Figure 1. The change of number of graduates from 2004 to 2012

Source: China Statistical Yearbook, from 2004 to 2012

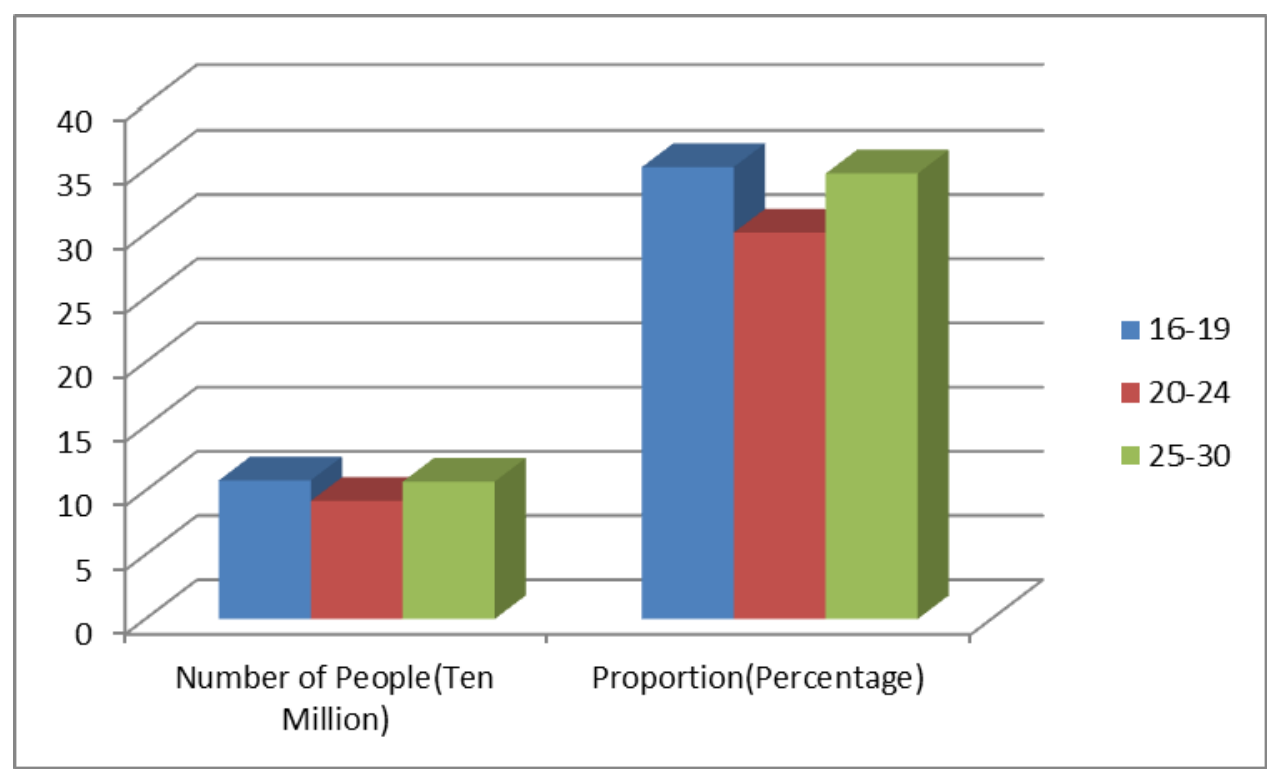

Figure 2. The number of people and proportion of various stages

Table 3. The registered urban unemployment rate from 2005 to 2011

\begin{tabular}{l|lllllll}
\hline Year & $\begin{array}{l}200 \\
5\end{array}$ & 2006 & 2007 & 2008 & 2009 & 2010 & 2011 \\
$\begin{array}{l}\text { Number } \\
\begin{array}{l}\text { Ten } \\
\text { Thousand }\end{array}\end{array}$ & 839 & 847 & 830 & 886 & 921 & 908 & 922 \\
\hline Percentage & 4.2 & 4.1 & 4.0 & 4.2 & 4.3 & 4.1 & 4.1 \\
\hline
\end{tabular}




\section{Ventures Model under the Juncture of Rural Land}

\subsection{Contracting and Establishing Rural Cooperatives to Realize Farm Produce'Industrial Production}

In the Process of economic development in China, the urban economy came from industrial-based economy to service-led economy. While the rural economy should achieve the transformation from dominated by the agriculture-based to industrial.Our country should reduce the proportion of primary industry in GDP, and improve the promotion of secondary and tertiary industries. College students have professional knowledge about management, business and other aspects. Young farmers have operating experience in agriculture. According to the principle of "the best use of the expertise and resources" ,we should explore the model of mutual cooperation business and contract farmers' land to establish of appropriate scale cooperatives. Cooperatives can involve planting food crops, cash crops, aquaculture and other rural backwardness that has owned originally. Through inputting factors of production and business model, we can achieve agricultural modernization, specialization and large-scale production. At the end, agricultural industrialization production will be achieved.

However, the accessing to rural and contract cooperatives to operate agricultural product for Chinese youth is not a simple matter. Young entrepreneurs should pay attention to the following aspects in order to improve the success rate of venture.

\subsubsection{Understand Agricultural Knowledge}

Before we try to set up the new cooperatives, we have to do the depth understand about agriculture. We can have a clear cognition with the following chart:

Table 4. Introduction of Chinese major crop

\begin{tabular}{lll}
\hline Region & Foods Crops & Economic Crops \\
\hline South of the Yangtze River & Rice & Cole,Tea,Cane \\
North of China & Wheat,Corn & Cotton \\
Northeast of China & Wheat,Corn, Sorghum, Millet & Beet, Soybean, Tobacco \\
Northwest of China & Wheat & Beet,Cotton \\
Xinjiang & Wheat & Cotton \\
Qinghai-Tibet & Livestock & \\
\hline
\end{tabular}

\subsubsection{Factor Supply}

Realizing the industrialization of agricultural requires adequate factors of production including large-scale mechanized equipment, capital, talent and so on then to reach modernization. People can lease large equipment to related companies early if the entrepreneur does not have enough funds. It Includes seedling pipeline unit (rice), transplanter (rice), planter (wheat and corn), harvesters, dryers, tractors, sprayers and other large mechanized equipment.

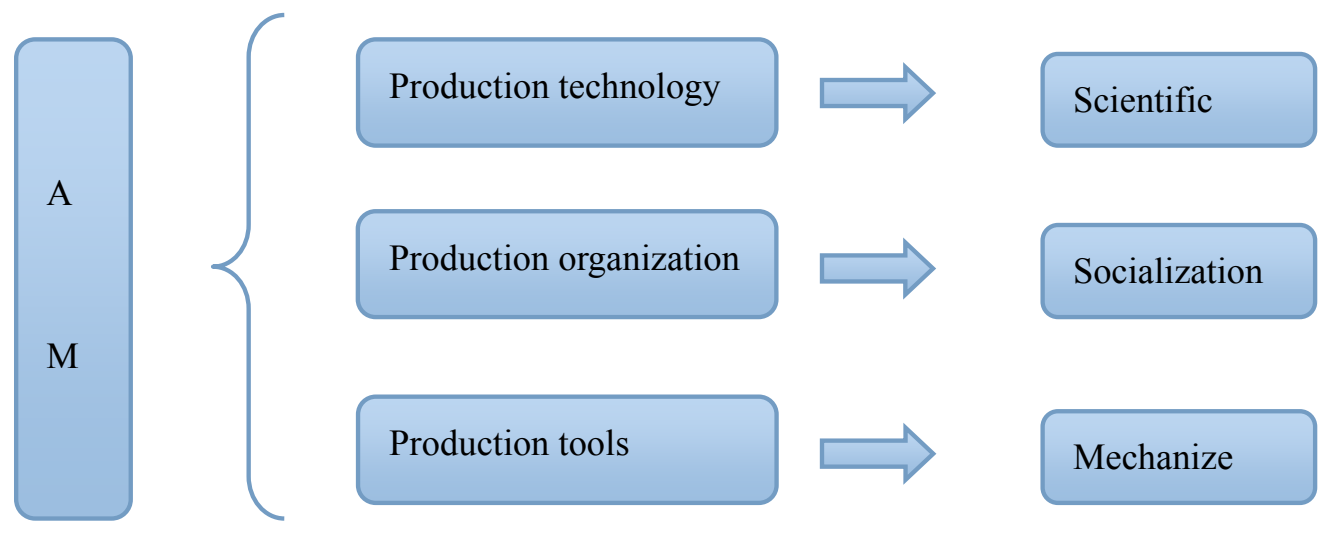

Figure 3.The characteristic of agricultural modernization. (Note: AM means “Agricultural Management”) 


\subsubsection{Labor-capital Relations}

Before starting a business, we must define labor relations clearly. Entrepreneurs can look for venture investment company to provide financial support.However, we must be sure to clear ratio of distribution of profit.

\subsubsection{Distribution of Benefits}

Before the large-scale production, youth should determine the distribution ratio of all aspects.Then they can sign a formal legal contract to guarantee the interests of landless peasants. The contract can cycle for three years or five years to prevent the situation that high-income farmers take rural land back to their hands for fear of interest dispute.

\subsubsection{Sales Channels}

After the realization of large-scale production of agricultural, products will be certainly generate largely. If we can not sell products out in time, it will lead to a reduction of income due to the elements about quality guarantee period and storage rates. Young entrepreneurs can transform agricultural products into futures to trade.Meanwhile,we can sale them by e-business.In addition,the product needs to be publicized through a variety of ways if necessary.

\subsection{Select the Land with Potential Development Resources to Carry out Tourism}

For some superior location, which have original ecology development potential or ethnic enclaves, you can try to develop the tourism.

\subsubsection{Development Elements}

In the course of rural tourism development, we should not only exploit the local resource,but also attach importance to the development of local culture, rural folk and other elements of the rich cultural connotations.

\subsubsection{Thoughtful Service}

It is the thoughtful idea that make an important role in tourism. We have to take tourist's physiologic,psychological and spiritual needs into account.For this reason, preparing a safe and comfortable environment for tourists and ensuring foods' and accommodation facilities' safe is necessary.

\subsubsection{Promotion by Propaganda}

At this stage, the degree of development is so far to enough. Traditional concept of farmers still in the stage that rural land can only be used for the cultivation of agricultural products. In addition, because of geographical reasons, many large areas which have the potential for tourism development are regarded as "kept in purdah did not know". Therefore, to emancipate farmer' mind by taking full advantage of the broadcast, television, newspapers, Internet and other modern media is the most pressing matter of the moment. We can also utilize agent computer such as travel agency to expand awareness of the new sight spots.

\section{Encourage Young People to Participate in Many Rural Entrepreneurship}

To encourage young people to achieve rural' venture and then to create jobs, we should change careers concept. In recent years, the government has introduced a series of policies about encouraging agricultural production to operate organized.

Table 5. Policies about encouraging organized operation from 2004 to 2013

\begin{tabular}{lllll}
\hline Years & $\begin{array}{l}\text { Leading } \\
\text { enterprises }\end{array}$ & Cooperative & $\begin{array}{l}\text { Social service } \\
\text { organizations }\end{array}$ & $\begin{array}{l}\text { New agricultural } \\
\text { production and } \\
\text { operation } \\
\text { organizations }\end{array}$ \\
\hline 2004 & $\begin{array}{l}\text { Increase } \\
\text { Investment }\end{array}$ & $\begin{array}{l}\text { Encourage the } \\
\text { development of } \\
\text { various types of } \\
\text { agricultural } \\
\text { cooperative } \\
\text { organizations }\end{array}$ & $\begin{array}{l}\text { Encourage the } \\
\text { development of } \\
\text { sellers and } \\
\text { purchaser of } \\
\text { large-scale }\end{array}$ & \\
\hline 2005 & Continue to & & \\
\hline 2006 & support & Actively guide & Foster new type \\
\hline
\end{tabular}




\begin{tabular}{|c|c|c|c|c|}
\hline & $\begin{array}{l}\text { lage quantity of } \\
\text { leading } \\
\text { enterprises with } \\
\text { strong } \\
\text { competitiveness } \\
\text { and driving force }\end{array}$ & $\begin{array}{l}\text { and support } \\
\text { building of } \\
\text { cooperatives }\end{array}$ & $\begin{array}{l}\text { of social service } \\
\text { organizations }\end{array}$ & \\
\hline 2007 & & $\begin{array}{l}\text { Rapid } \\
\text { development }\end{array}$ & $\begin{array}{l}\text { Accelerate the } \\
\text { development of } \\
\text { rural } \\
\text { brokers,circulatio } \\
\mathrm{n} \text { intermediary }\end{array}$ & \\
\hline 2008 & $\begin{array}{l}\text { Strengthen the } \\
\text { leading } \\
\text { enterprises with } \\
\text { strong } \\
\text { competitiveness }\end{array}$ & $\begin{array}{l}\text { Positive } \\
\text { development }\end{array}$ & $\begin{array}{l}\text { Positive } \\
\text { development }\end{array}$ & \\
\hline 2009 & $\begin{array}{l}\text { Support } \\
\text { development }\end{array}$ & $\begin{array}{l}\text { Support } \\
\text { development }\end{array}$ & & \\
\hline 2010 & & $\begin{array}{l}\text { Vigorous } \\
\text { development }\end{array}$ & $\begin{array}{l}\text { Positive } \\
\text { development of } \\
\text { all kinds of Social } \\
\text { service } \\
\text { organizations }\end{array}$ & \\
\hline 2012 & & $\begin{array}{l}\text { Support the } \\
\text { Cooperative to } \\
\text { establish } \\
\text { enterprise and } \\
\text { shares the leading } \\
\text { enterprise }\end{array}$ & $\begin{array}{l}\text { Foster and support } \\
\text { establishment of } \\
\text { new stype of } \\
\text { social service } \\
\text { organizations }\end{array}$ & \\
\hline 2013 & $\begin{array}{l}\text { Foster and } \\
\text { strengthen the } \\
\text { leading enterprise }\end{array}$ & $\begin{array}{l}\text { Develop all kinds } \\
\text { of new rural } \\
\text { cooperative } \\
\text { organization }\end{array}$ & & $\begin{array}{l}\text { Support Union } \\
\text { household } \\
\text { operations, } \\
\text { Professional large } \\
\text { house and Family } \\
\text { farm }\end{array}$ \\
\hline
\end{tabular}

Social forces should be given support, specifically including the following aspects:

\subsection{Transform Training Model and Focusing on Education of Venture Awareness}

Universities should change the training model, strengthen practical education, deepen theoretical knowledge, convert knowledge into ability during college students' learning. Schools can cooperate with factory, company and various forms of social organization to build practice base with sufficient quantity, anastomosis subject and chances of Win-win situation. All the work lead to the situation that Practice Base will be an important platform for the practice of teaching students.

\subsection{Government Should Increase Support to Ensure the Smooth Progress of Entrepreneurship}

\subsubsection{Financial Support}

The Third Plenary Session of the eighth point that the Government should encourage rural to develop cooperative economy and realize large-scale, professional and modern management. Financial funds should be invested in eligible cooperatives directly. Apart from this, assets formed by financial assistance can be hold and managed. 
Table 6. The proportion of financial support for agriculture

\begin{tabular}{llllllll}
\hline Year & 1991 & 1992 & 1993 & 1994 & 1995 & 1996 & 1997 \\
\hline Rate(\%) & 10.3 & 10.0 & 9.5 & 9.2 & 8.4 & 8.8 & 8.3 \\
\hline
\end{tabular}

Source: Japan's construction of modern agriculture and reference model

\subsubsection{Taxation Support}

For rural youth who start their own business, the government should impose sales tax depending on the circumstances for fear of imposing overfull tax of cooperatives. Such behavior can put more money into the next cycle of the production process circular.

\subsubsection{Policy Protection}

Governments should be given protection of policy when the youth encounter various obstacles in the process of running. For example, they can give appropriate subsidy to entrepreneurs if irresistible natural disasters come.In addition, the level of development of modern agricultural technology has an important role in promoting agriculture.

Table 7. The contribution rate of science and technology of China in each state

\begin{tabular}{ll}
\hline Different States & The contribution rate of science and technology(\%) \\
\hline First Five-Year Plan(1953-1957) & 20 \\
Fifth Five-Year Plan(1976-1980) & 47 \\
Ninth Five-Year Plan(1996-2000) & 40 \\
Tenth Five-Year Plan(2001-2005) & 45 \\
\hline
\end{tabular}

\subsection{Banks Provide Capital Funds to Lower the Threshold of Loan}

In China,the total number of rural loans are extremely disproportionate with economics status of rural.From the statistics over the years, the proportion of enterprise' total loan from rural and township account for the total loan from financial institutions is far less than the specific gravity of added value from villages and towns account for the GDP.We can find oue the change from the following chart over the years.

Table 8. Disparity of some years

\begin{tabular}{ll}
\hline Years or Interval & Disparity(\%) \\
\hline $1978-1985$ & $20-30$,average 26 \\
$1986-1988$ & $<20$ \\
1989 & 23.76 \\
1994 & 32.29 \\
2005 & 27.58 \\
After 2007 & $>30$ \\
\hline
\end{tabular}

It is the funds that make an important role in the course of running company because of the truth that they don't have enough deposit. So banks can provide appropriate credit support for entrepreneurs to achieve credit cooperative. For instance, measures can be involved with reducing the lending rates, developing new loans products, simplifying the loan process, raising the loan amount and so on. Only in this way, young entrepreneurs are confident in the funds available and then spare no efforts to threw himself into operation.

\subsection{Company Invest Agriculture and Change the Pattern of Agricultural Markets}

\subsubsection{Device Support}

In the process of agricultural industrialization, it is essential to use some large and modernization equipment. For 
them, it is hard to bear. Equipment manufacturers can rent to users to bring about high-efficiency production mode.

\subsubsection{Transportation Security}

Traffic flow will be significantly increased after the large-scale production of agriculture. Large vehicles are often used to transport products which need to be sold abroad to the appropriate ports, especially in those days which are not suitable for transportation. Importance should be attached to transportation issue for the reason that if similar things happen, it brings not only losing assets but also lacking of credit.

\subsubsection{Exposures}

For fear of happening of natural disasters and other unforeseen factors, entrepreneurs can establish collaboration with Insurance Companies to minimize the loss of capital.

\section{Conclusion}

Solving the problem of youth employment is not only the importance of protecting and improving people's livelihood but also referring to the long-term development of society. What's more, encouraging young to go to the countryside to boost employment through entrepreneurship is an effective way under the situation of the New Pattern of Integration of Urban and Rural Areas. For this reason, kinds of social forces should actively encourage and guide the youth to foster awareness of rural entrepreneurship.

\section{References}

Chen, Lian. (2013). Study on Enterprise Development of Agriculture of China. Beijing: Economics Research Department, Central Party School.

Feng, Jingcai. (2010). A Comparative Study of Modern Agriculture in France, Japan, and the United States. Northeast Asia Research Institute.

Hou, Jianping. (2007). Study on Choice of Precision Agriculture Developing Mode and Evaluation. Tianjin: School of Management, Tianjin University.

Lang, Xiuyun. (2008). Modern Agriculture: American Model and Chinese Road. Research of Theory of Mao Zedong and Deng Xiaoping.

Li, Lina. (2009). Development Model of Modern Agriculture of American and Japan. Exotic Observation.

Li, Tongguo. (2011). The Analysis of Element and Countermeasure of Difficile Employment of China Youth. Sichuan: Student Office, Leshan Teachers College.

Research Group of China Youth Research Center. (2009). The Research Report of Employment and Entrepreneurship Status of China Youth. Chinese Communist Youth League.

Zhang, Weihua. (2010). The Reason and Countermeasure of the Plight of Rural Youth Employment. Xi'an: Northwest AF University. 